\title{
EFFECTS OF SODIUM CHLORIDE ON THE ENGINEERING PROPERTIES OF EXPANSIVE SOILS
}

\author{
Durotoye T.O ${ }^{1}$, Akinmusuru J.O.$^{2}$

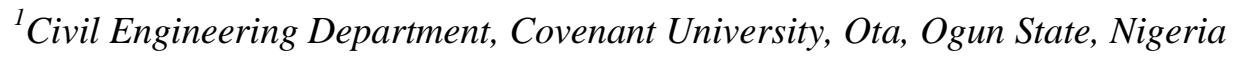 \\ taiwo.durotoye@covenantuniversity.edu.ng \\ ${ }^{2}$ Civil Engineering Department Covenant University, Ota, Ogun State, Nigeria \\ joseph.akinmusuru@covenantuniversity.edu.ng
}

\begin{abstract}
This paper investigated the effect of sodium chloride on some geotechnical properties of expansive soil for highway pavement (subgrade) works. In this study, engineering properties including; Natural water content, Atterberg limits, specific gravity, compaction, free swell index, unconfined compressive strength, soaked and unsoaked California bearing ratio were determined in the laboratory and their behavior on stabilizing with various percentages of sodium chloride (0, 0.5, 1.0, 1.5. 2.0 and 2.5) investigated. From the study, plastic limit, liquid limit, plasticity index, linear shrinkage, specific gravity, free swell index and optimum water content values of the stabilized soil reduced, while the maximum dry density, California bearing ratio and unconfined compressive strength values increased. The highest reduction percentages of $60.42 \%$ (131 to $51.85 \%)$, $42.86 \%$ (50.00 to $28.57 \%$ ), $71.26 \%$ (81.00 to $23.28 \%$ ), $66.64 \%$ (15.11 to $5.04 \%$ ), $83.43 \%$ (115.00 to $19.05 \%$ ), and $28.57 \%(28.00$ to $20.00 \%)$ in liquid limit, plastic limit, plasticity index, linear shrinkage, free swell index and optimum water content respectively; and maximum percentage increase of $11.38 \%$ (1.67 to $1.86 \mathrm{~g} / \mathrm{m} 3$,on maximum dry density), $31.78 \%$ (29.20 to $38.48 \%$, on unsoaked CBR), $257.67 \%$ (4.3 to $15.38 \%$, on soaked CBR), and $26.98 \%$ ( 67.86 to $86.17 \mathrm{kN} / \mathrm{m} 2$ on unconfined compressive strength) were obtained on treatment of the soil with $1.5 \%$ sodium chloride by weight. Treatment of the soil with sodium chloride has thus reduced its swelling potential and increased the strength
\end{abstract}

Keywords: Expansive Soil, Sodium Chloride, Strength Parameters, Subgrade, Engineering Properties. $* * *$

\section{INTRODUCTION}

Soil is one of the most commonly encountered materials in civil engineering. All the structures, except some which are founded on solid rock, rest ultimately on soil. Geotechnical engineers all over the world face huge issues, when structures founded on the soil are expansive in nature. Expansive soils are those soils which show substantial volume variations as a result of water content changes. This type of soil, upon swelling and shrinking, causes severe impairment to pavement constructed on them (Zumrawi and Hamza, 2014). These soils swell when giving access to water and shrink after they dry out. (Al-Rawas, et al., 2002).

Soils can be difficult in geotechnical engineering because they swell, shrink and experience excessive settlement with a deficiency of strength, (Owolabi and Ola, 2014). Expansive soil occupies about $20 \%$ of the world surface area (Chaitanya, et al., 2011.). These soils are capable of absorbing large volumes of water due to the presence of montmorillonite in their mineralogy (Ola, 1981). Expansive soils are located all over the globe. They also exist abundantly in the northeastern part of Nigeria. They present various challenges owing to their features of extreme swelling, shrinking and numerous loss of strength, (Sabat, 2012).

Soil stabilization is widely known as an effective alternative for improving soil properties. Stabilization can be derived from mechanical or chemical means. Mechanical stabilization, or compaction, is the densification of soil by application of mechanical energy. Chemical stabilization involves mixing or injecting soil with chemically active compounds such as cement, lime, fly ash, calcium or sodium chloride or with viscoelastic materials such as bitumen (Zumrawi, 2015). Among these, the most widely used chemical additives are cement, lime and fly ash, (Petry and Little, 2002). These additives are most frequently associated with improving the strength and reducing the swelling properties of expansive soils. The main application of sodium chloride is in long-term highway pavement subgrade. (Singh and Das, 1999).

(Prakhar and Rajesh, 2015) investigated the effect of common salt $(\mathrm{NaCl})$ on engineering properties of black cotton soil. The soil was mixed with Common Salt $(\mathrm{NaCl})$ at $0 \%, 2 \%, 4 \%, 6 \%$ and $8 \%$. Common Salt $(\mathrm{NaCl})$ content (by dry weight of soil) to investigate their effect on some geotechnical characteristics in the laboratory, the results show that the free swell index and optimum moisture content decreases with increase in $\mathrm{NaCl}$ concentration and the maximum dry density, California bearing ratio and the unconfined compressive strength increases with increase in $\mathrm{NaCl}$ concentration. (Kumar, et al., 2015) studied the effect of Salinity on geotechnical properties of expansive soils carried out using inorganic salt solutions such as $\mathrm{NaCl}$ at three types of concentrations $(0.001,0.01,0.05)$, the results show that the liquid limit, plastic limit, free swell index, optimum moisture content decreases with increase in the salt solutions and the maximum dry density and unconfined 
compressive strength increases with increase in the salt solutions. (Ramadas, et al., 2012) studied the effect of various percentage of calcium chloride such as $0.5 \%, 1.0 \%$, $1.5 \%$ and $2 \%$ on the engineering properties of three expansive soils and the result shows reduced plasticity and increased the strength of the soils. (Amu, et al., 2005) studied the stabilization of an expansive clay soil with the combination of cement and fly ash. The results showed that the soil sample stabilized with a mixture of cement and fly ash had better performance with attention to maximum dry densities, optimum moisture content, bearing capacity and shearing resistance tests.

This research work involved collection of representative samples of expansive soils from Ifo locality in Ogun State. Their assessment in the laboratory to evaluate the suitability of sodium chloride on the engineering properties of expansive soils for highway pavement subgrade. Highway pavements or roads constructed on active zone of expansive subgrade soils experience failures as a result of volume changes or swelling associated with seasonal changes in the moisture content of the soil. Road failure has become a key difficulty in Nigeria as well as most countries of the world. The most disturbing aspect is that even new roads constructed experience failures at different points in less than six months or about a year (Aderinola and Owolabi, 2014).

Figure 1, shows road failure caused by expansive soils in Oniyale, ifo locality, where the expansive soil was collected.

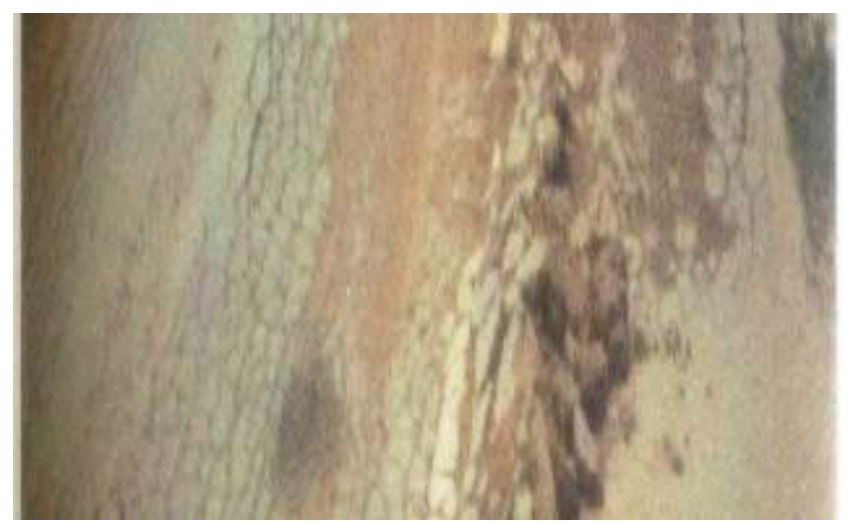

Figure 1: Longitudinal Cracks On A Highway Pavement At Oniyale, Ifo Locality.

The aim of this research therefore, is to evaluate the suitability of sodium chloride on the engineering properties of expansive soils with different percentages in the laboratory. The result of the study were used to evaluate, compare results of different mixes and to generate a mix which can safely be used for improvement of the soil and hence mitigation of the swelling problems (expressed as cracks) experienced by highway pavements (roads) built on the soil.

\section{MATERIALS AND METHODS}

The materials used in the study are sodium chloride and expansive soil. Common Salt is white in color and is in the form of crystals. It is hygroscopic; it absorbs and retains moisture. It has electrolytic and crystal forming properties but is not strongly deliquescent; it absorbs moisture only when the relative humidity is above $75 \%$. It lowers the vapor pressure of water. Common salt falls under waterretaining agents used in soil stabilization to improve soil strength, bearing capacity and durability under adverse moisture and stress conditions; it reduces or prevents frost heave in soil by lowering the freezing point of water. It is very effective as dust palliative. It checks the formation of shrinkage cracks; it also reduces changes in moisture content by forming barrier to the movement of water in the liquid phase. In addition, sodium chloride has a very stable configuration due to the electrovalent or ionic type of bond it possesses. Sodium chloride is extensively used in many chemical industries.

The expansive soil used in this study was collected from Ifo locality in Ogun state. Its liquid limit and plastic limit are found to be $131 \%$ and $50 \%$. As per unified soil classification system for fine grained soil, the expansive soil is classified as clay of high plasticity. The soil sample was subjected to geotechnical tests in the laboratory including, natural moisture content, atterberg limits (liquid limit, plastic limit and shrinkage Limit), specific gravity, free swell index, proctor compaction, California bearing ratio (CBR) and unconfined compression strength (UCS).

The sample used for the study was air dried, it was further pulverized and sieved through a sieve of $4.75 \mathrm{~mm}$ to eliminate gravel fraction. This air dried and sieved soil was stored in airtight containers for stabilization. The soil sample kept for stabilization was mixed with sodium chloride solutions of varying concentrations, prepared by dissolving sodium chloride powder in distilled water. The concentrations prepared are: $0 \%, 0.5 \%, 1.0 \%, 1.5 \%, 2.0 \%$, and $2.5 \%$, and various engineering properties were studied by conducting the experiments. The overall testing program was conducted in two phases. In the first phase the index properties and engineering properties of the soils were studied by conducting laboratory experiments. In the second phase, soils were mixed with $0.5 \%, 1.0 \%, 1.5 \%, 2.0 \%$ and $2.5 \%$ of $\mathrm{NaCl}$ by dry weight of soil. The tests were performed according to British standard methods of test for soil for civil engineering purposes (BS 1377: Part 1-9, 1990) and the test determination of the various properties, discussed herewith.

The Natural Water Content was determined according to the specification of the Test 1 (A) of BS 1377 (1990). 50g of crushed soil samples were weighed in two aluminum containers. The weights of the container and container plus soil were read to the nearest $0.1 \mathrm{~g}$. The samples were oven dried for 18 hours at $105^{\circ} \mathrm{C}$ to $110^{\circ} \mathrm{C}$ thermostatically controlled temperature. The natural water content was determined from the expression:

Water content $(\%)=\mathrm{W}_{2}-\mathrm{W}_{3} / \mathrm{W}_{3}-\mathrm{W}_{1}$

$\mathrm{W}_{1}=\mathrm{Wt}$. of empty container + lid $(\mathrm{g})$

$\mathrm{W}_{2}=\mathrm{Wt}$. of container + lid + wet soil $(\mathrm{g})$

$\mathrm{W}_{3}=\mathrm{Wt}$. of container + lid + dry soil $(\mathrm{g})$

Atterberg Limits Test: liquid limit, plastic limit, plasticity index and shrinkage limit of soil passing BS $425 \mu \mathrm{m}$ sieve according to the specification of the Test 1 (A) of BS 1377 1990 were determined. The soil was mixed with the various 
percentage concentrations $(0.5,1.0,1.5,2.0,2.5)$ of salt by weight this test was performed at different concentrations according to the specification of the Test 1 (A) of B.S 1377 (1990).

The Specific gravity (G) Test: of the soil has been determined using pycnometer in accordance with BS 1377 (1990).

Standard Proctor Compaction Test: The soil sample was oven dried at $105^{\circ} \mathrm{C}$ to $110^{\circ} \mathrm{C}$ thermostatically controlled temperature, for about 24 hours. In accordance with BS 1377 (1990). The soil was mixed with the various percentage concentrations $(0.5,1.0,1.5,2.0,2.5)$ of salt by weight and then this mix were compacted in three equal layers with increase water content. after which based on the compaction curves plotted for the different mixes, optimum moisture content (OMC) and maximum dry density (MDD) for each test specimens were obtained.

Unconfined Compressive Strength Test: The unconfined compressive strength of the cylindrical shaped specimens (50 $\mathrm{mm}$ diameter and $100 \mathrm{~mm}$ length) were determined according to BS 1377 (1990). The cylindrical specimen was placed on the base plate and the load frame has been fixed without any stress application upon the specimen. The geotechnical properties of these sodium chloride stabilized soil samples were evaluated and compared with that of soil before stabilization.

\section{RESULTS AND DISCUSSION}

A summary of the engineering properties of the natural soil is shown in Table 1. The soil is classified as Clay of high plasticity $(\mathrm{CH})$ in accordance with Unified Soil Classification System, (USCS). The high values of the Atteberg limits (linear shrinkage, plasticity index, plastic limit and liquid limit), $15.11 \%, 81 \%, 50 \%$ and $131 \%$, respectively, of the untreated soil (Table 1) are indications of high swelling potential and critical degree of expansion of the soil, which agree with (Ola, 1981), swelling potential classification of expansive soil as shown in Table 4.
Table 1: The Properties Of The Expansive Soil Used For The Study

\begin{tabular}{|l|l|l|}
\hline S/N & Property & Value \\
\hline 1 & natural moisture content & $23.6 \%$ \\
\hline 2 & liquid limit & $131 \%$ \\
\hline 3 & plastic Limit & $50 \%$ \\
\hline 4 & plasticity Index & $81 \%$ \\
\hline & USCS CLASSIFICATION & $\mathrm{CH}$ \\
\hline 5 & shrinkage limit & $15.11 \%$ \\
\hline 6 & specific gravity & 2.74 \\
\hline 7 & $\begin{array}{l}\text { proctor compaction } \\
\text { (a) optimum moisture }\end{array}$ & $28 \%$ \\
& $\begin{array}{l}\text { Content (OMC) density } \\
\text { (b) maximum dry }\end{array}$ \\
& (MDD) & $1.67 \mathrm{~g} / \mathrm{cm}^{3}$ \\
\hline 8 & free swell index (FSI) & $115 \%$ \\
\hline 9 & California bearing ratio (unsoaked & $29.2 \%$ \\
& CBR) (soaked & $4.3 \%$ \\
& California bearing ratio & \\
\hline 10 & CBR) unconfined compression strength & $67.86 \mathrm{kN} / \mathrm{m}^{2}$ \\
& (UCS) & \\
\hline
\end{tabular}

Table 2 shows the effect and extent of reduction on treatment of sodium chloride on the engineering properties of studied expansive soil. On addition of $0.5 \%$ of sodium chloride to the soil, rapid rate of reduction percentages of $20.61 \%$ (131.00 to $104.00 \%$ on liquid limit), $24.90 \%$ (81.00 to $60.83 \%$, on plasticity index) and $33.36 \%$ (15.11 to $10.07 \%$, on linear shrinkage) were observed. Optimal addition of $1.5 \%$ of sodium chloride led to maximum reduction percentage of $60.42 \%$ (131 to $51.85 \%$, on liquid limit), $42.86 \%$ (50.00 to $28.57 \%$, on plastic limit), 71.26 $\%$ (81.00 to $23.28 \%$, on plasticity index), $66.64 \%$ (15.11 to $5.04 \%$, on linear shrinkage), $83.43 \%$ (115.00 to 19.05 ,on free swell index), and $28.57 \%$ (28 to $20 \%$,on optimum moisture content)

Table 2: Effect And Extent Of Reduction (\%) On Treatment Of Nacl On Engineering Properties Of Studied Expansive Soil

\begin{tabular}{|l|c|l|l|l|l|l|}
\hline $\mathrm{NaCl}$ content (\%) & 0 & 0.5 & 1.0 & 1.5 & 2.0 & 2.5 \\
\hline Liquid Limit (\%) & 131.00 & 104.00 & 85.71 & 51.85 & 51.72 & 51.35 \\
\hline \% Reduction & - & 20.61 & 45.29 & 60.42 & 60.52 & 60.80 \\
\hline Plastic Limit (\%) & 50.00 & 43.17 & 37.63 & 28.57 & 28.54 & 28.44 \\
\hline \% Reduction & - & 13.66 & 24.74 & 42.86 & 42.92 & 43.12 \\
\hline Plasticity Index (\%) & 81.00 & 60.83 & 48.08 & 23.28 & 23.18 & 22.91 \\
\hline \% Reduction & - & 24.90 & 40.64 & 71.26 & 71.38 & 71.72 \\
\hline Linear Shrinkage Limit (\%) & 15.11 & 10.07 & 6.47 & 5.04 & 5.04 & 5.04 \\
\hline \% Reduction & - & 33.36 & 57.18 & 66.64 & 66.64 & 66.64 \\
\hline Specific gravity & 2.74 & 2.71 & 2.68 & 2.64 & 2.63 & 2.62 \\
\hline \% Reduction & - & 1.09 & 2.19 & 3.65 & 4.01 & 4.38 \\
\hline OMC (\%) & 28 & 24 & 22 & 20 & 20 & 19 \\
\hline \% Reduction & - & 14.29 & 21.43 & 28.57 & 28.57 & 32.14 \\
\hline Free Swell Index (\%) & 115.00 & 80.95 & 42.85 & 19.05 & 18.10 & 16.67 \\
\hline \% Reduction & - & 29.61 & 62.74 & 83.43 & 84.26 & 85.50 \\
\hline
\end{tabular}


Table 3 shows the effect and extent of $(\%)$ increase on treatment of sodium chloride on the engineering properties of studied expansive soil. Optimal addition of $1.5 \%$ of sodium chloride led to maximum percentage increase of
$11.38 \%$ (1.67 to $1.86 \mathrm{~g} / \mathrm{m}^{3}$, on maximum dry density), 31.78 $\%$ (29.20 to $38.48 \%$, on unsoaked CBR), $257.67 \%$ (4.3 to $15.38 \%$, on soaked CBR), and $26.98 \%$ ( 67.86 to 86.17 $\mathrm{kN} / \mathrm{m}^{2}$ on unconfined compressive strength).

Table3: Effect And Extent Of (\%) Increase On Treatment Of Nacl On Engineering Properties Of Studied Expansive Soil

\begin{tabular}{|l|l|l|l|l|l|l|}
\hline $\mathrm{NaCl}(\%)$ & 0 & 0.5 & 1.0 & 1.5 & 2.0 & 2.5 \\
\hline $\mathrm{MDD}\left(\mathrm{g} / \mathrm{cm}^{3}\right)$ & 1.67 & 1.80 & 1.83 & 1.86 & 1.85 & 1.84 \\
\hline$(\%)$ Increase & - & 7.78 & 9.58 & 11.38 & 10.78 & 10.18 \\
\hline $\mathrm{CBR}$ : unsoaked (\%) & 29.20 & 32.60 & 34.93 & 38.48 & 38.35 & 38.20 \\
$(\%)$ Increase & - & 11.64 & 19.62 & 31.78 & 31.34 & 30.82 \\
soaked (\%) & 4.30 & 9.75 & 11.00 & 15.38 & 15.28 & 15.10 \\
$(\%)$ Increase & - & 126.74 & 155.81 & 257.67 & 255.35 & 251.16 \\
\hline unconfined compressive strength $\left(\mathrm{kN} / \mathrm{m}^{2}\right)$ & 67.86 & 74.15 & 78.69 & 86.17 & 84.16 & 82.67 \\
\hline$(\%)$ Increase & - & 9.27 & 15.96 & 26.98 & 24.02 & 21.82 \\
\hline
\end{tabular}

The variation of liquid limit and plasticity index with $\mathrm{NaCl}$ content for the stabilized expansive soil is shown in Fig.2. liquid limit and plasticity index decreases with higher $\mathrm{NaCl}$ content, which is in agreement with the findings made by (Kumar, Smitha and Uday, 2015) and (Ramadas, Kumar, and Yesuratnam, 2012)

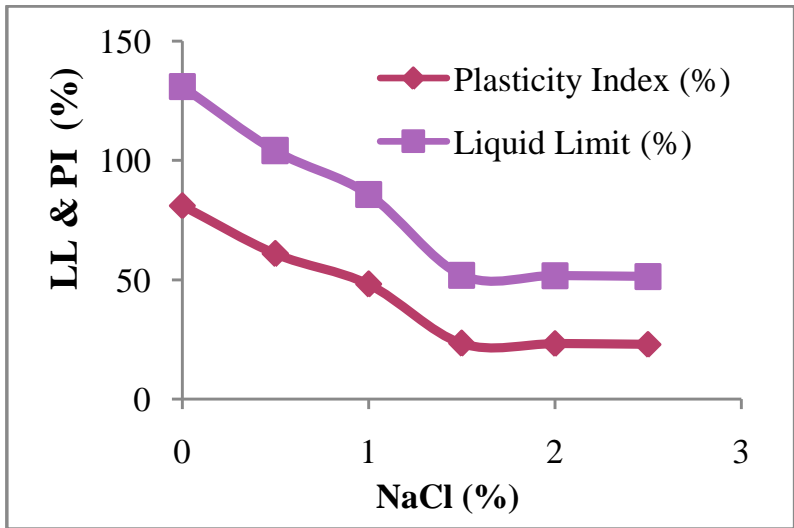

Figure 2: Variation of liquid limit and plasticity index of soil with different sodium chloride (\%).

The variation of shrinkage limit with $\mathrm{NaCl}$ content for the stabilized expansive soil is shown in Fig.3. shrinkage limit decreased with higher $\mathrm{NaCl}$ content, which is also in agreement with the findings made by (Kumar, Smitha and Uday, 2015) and (Ramadas, Kumar, and Yesuratnam, 2012).

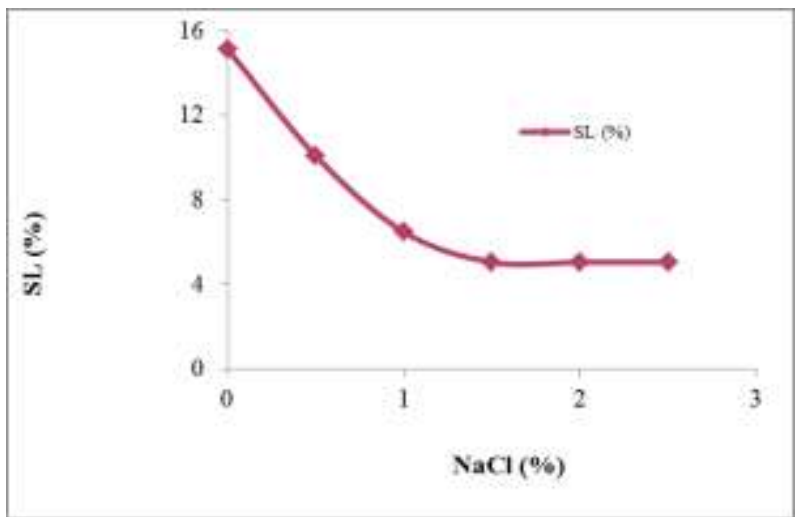

Figure 3: Variation Of Shrinkage Limit Of Soil With Different Sodium Chloride (\%).
Figure 4,5,6,7 and 8 agrees with Prakhar and Rajesh 2015) and (Kumar, Smitha and Uday, 2015) that the optimum moisture content and the free swell index decreases with increase in $\mathrm{NaCl}$ concentration and the maximum dry density, California bearing ratio and the unconfined compressive strength increases with increase in $\mathrm{NaCl}$ concentration.

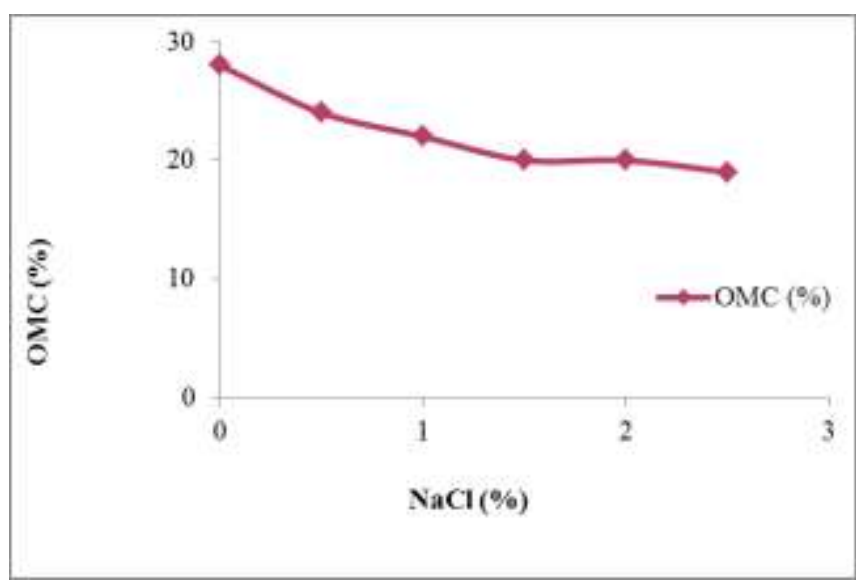

Figure 4: Variation of optimum moisture content with different sodium chloride (\%).

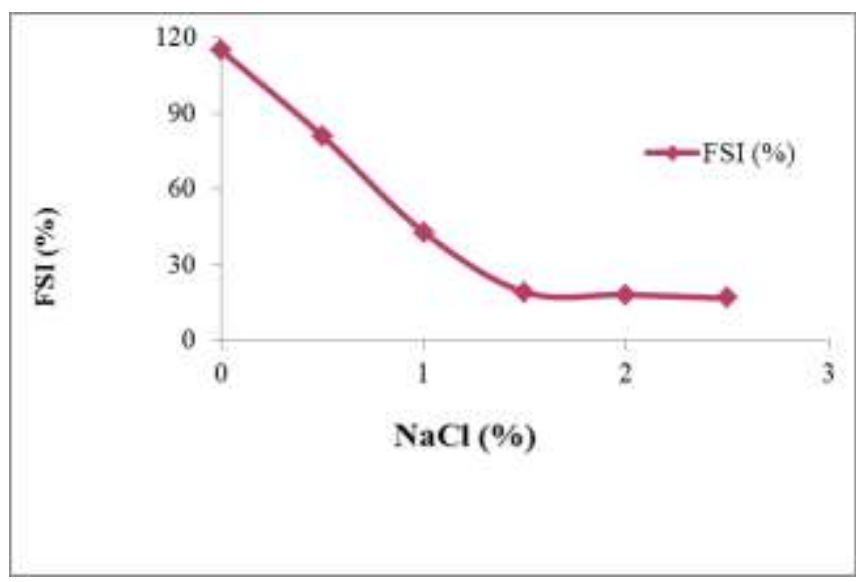

Figure 5: Variation of free swell index of soil with different sodium chloride (\%). 


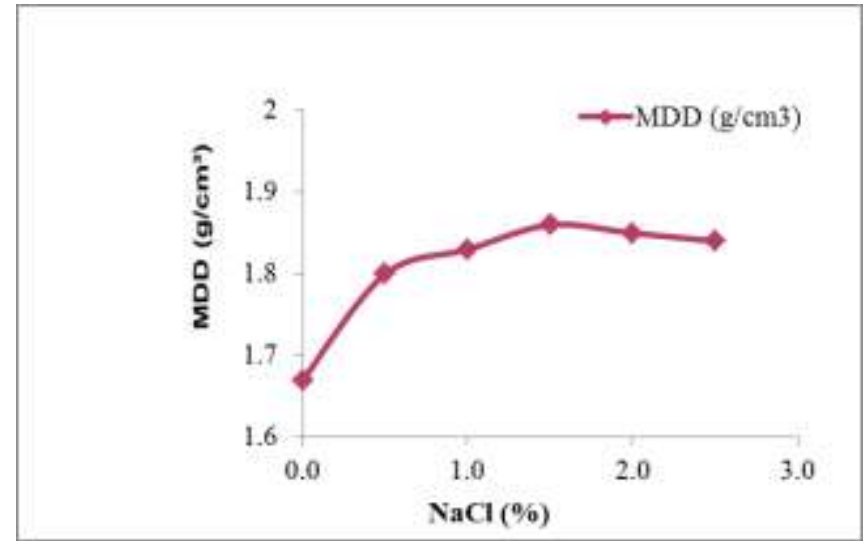

Figure 6: Variation of maximum dry density of soil with different sodium chloride $(\%)$.

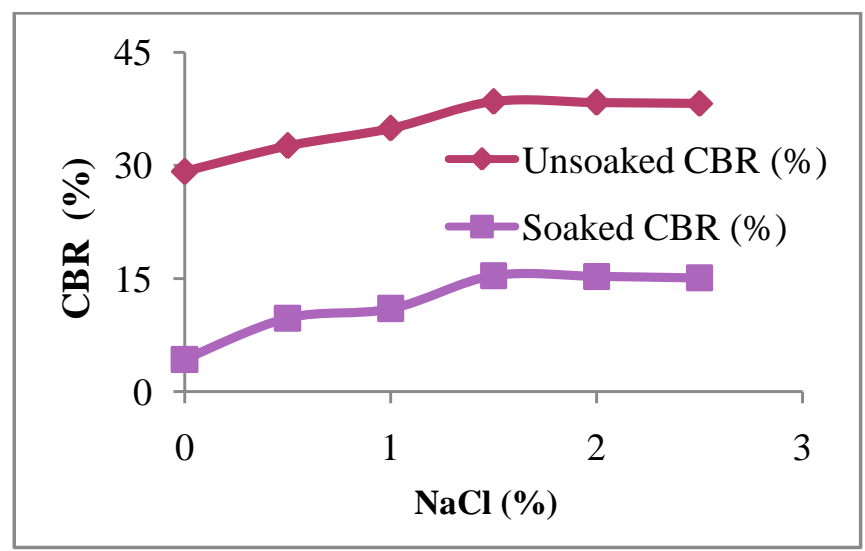

Figure 7: Variation of soaked and unsoaked CBR of soil with different sodium chloride $(\%)$.

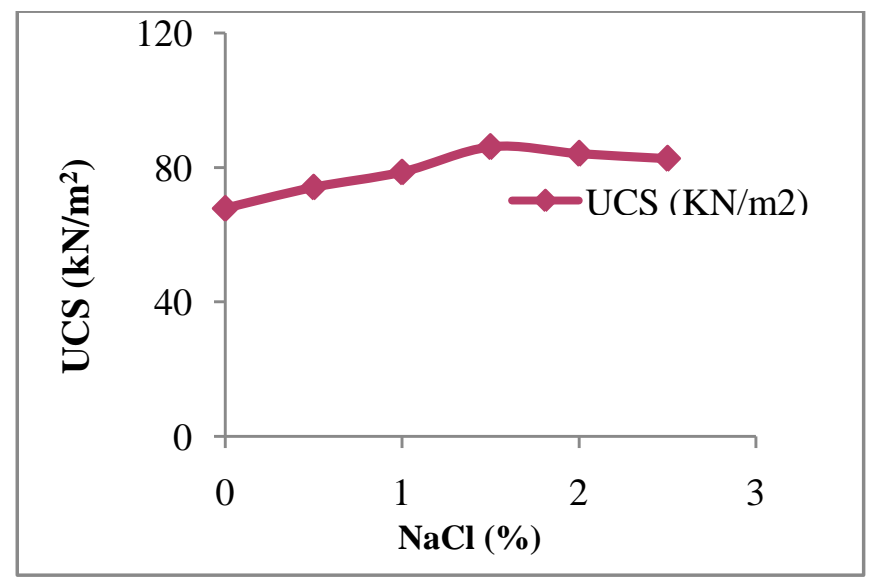

Figure 8: Variation of Unconfined Compressive Strength of soil with different sodium chloride (\%).

From the study, treatment of expansive subgrade soil with different percentages of sodium chloride has the effect of reducing the liquid limit, plastic limit, plasticity index, linear shrinkage, free swell index and the optimum moisture content. (Swelling indicators) and increasing the maximum dry density, California bearing ratio $(\mathrm{CBR})$ and the unconfined compressive strength (Strength characteristics).

Table 4 shows the swelling potential classification of expansive soil based on the plasticity index and liquid limit $(\mathrm{Ola}, 1981)$
Table 4: Classification of expansive soils on the basis of plasticity index (PI) and liquid limit (LL) (Ola, 1981)

\begin{tabular}{|l|l|l|}
\hline Swelling potential & PI $(\%)$ & LL $(\%)$ \\
\hline Low & $<15$ & $<35$ \\
\hline Moderate/medium & $15-25$ & $35-50$ \\
\hline High & $25-35$ & $50-70$ \\
\hline Very High & $>35$ & $>70$ \\
\hline
\end{tabular}

\section{CONCLUSION}

[1]. Treatment of the studied expansive soil has the effect of reducing the values of the geotechnical index properties (liquid limit, Plasticity index and linear shrinkage, free swell index) of the soil and hence its tendency to swell; and increasing the strength characteristics (California Bearing Ratio, Maximum Dry Density and the Unconfined Compressive Strength).

[2]. On addition of $1.5 \%$ sodium chloride to the soil, maximum reduction percentage of $60.42 \%$ (131 to $51.85 \%$, on liquid limit), $42.86 \%$ (50.00 to $28.57 \%$, on plastic limit), $71.26 \%$ ( 81.00 to $23.28 \%$, on plasticity index), $66.64 \%$ (15.11 to $5.04 \%$, on linear shrinkage), $83.43 \%$ (115.00 t0 19.05,on free swell index), and $28.57 \%$ (28.00 to $20.00 \%$, on optimum moisture content) were obtained.

[3]. Using Ola (1981) swelling potential classification of expansive soils based on Plasticity Index values, the treatment reduced the Swelling Potential of the soil from high to moderate (81.00 to $23.28 \%$ ),

[4]. On addition of $1.5 \%$ sodium chloride to the soil, maximum percentage increase of $11.38 \%$ (1.67 to $1.86 \mathrm{~g} / \mathrm{m}^{3}$, on Maximum dry density), $31.78 \%$ (29.20 to $38.48 \%$, on unsoaked CBR), $257.67 \%$ (4.3 to $15.38 \%$, on soaked CBR), and $26.98 \%$ ( 67.86 to $86.17 \mathrm{kN} / \mathrm{m}^{2}$ on Unconfined compressive strength) were obtained. These increases represent improvements in strength characteristics of the treated subgrade soil.

\section{ACKNOWLEDGEMENT}

The author acknowledges the Department of Civil Engineering, Covenant University for providing the laboratory facilities to undertake this study.

\section{REFERENCE}

[1]. Aderinola, O.S. and Owolabi ,T.A (2014). An Investigation into Early Road Failure in Nigeria: Mechanistic Analysis of Road Note 31. International Journal of Novel Research in Engineering and Applied Sciences . Vol 1(1)

[2]. Al- Rawas, A.A, Taha R, Nelson J.B, Belt Al-Shab, T and AL-Siyabi, H. (2002). A comparative evaluation of various additives used in the stabilization of expansive soils. Geotechnical Testing Journal, Vol 25(2).

[3]. Amu, O.O, Fajobi, A.B, and Afekhuai, S.O (2005). Stabilizing potential of cement and fly ash mixture on expansive clay soil. Journal of Applied Sciences. Vol $5(9)$. 
[4]. British Standard 1377, (1990), Methods of test for soils for civil engineering purposes. London: British Standard Institution.

[5]. Chaitanya, G Kesava N k, Raju, Prasada G. V .R and Ramu, K (2011). Evaluation Studies Of Expansive Soil Treated With Electrolytes. International Journal of Engineering Science and Technology. Vol 3 (12)

[6]. Kumar, Bale Nikhil, Smitha, Jeevana, Uday, K.V,(2015). Effect of Salinity on Geotechnical Properties of Expansive Soils. International Journal of Innovative Research in Science, Engineering and Technology. Vol 4(7)

[7]. Ola, S. A. (1981). Mineralogical properties of some Nigerian residual soils in relation with building problems. Engineering Geology, Vol.19 (1)

[8]. Owolabi, T.A. and Aderinola, O.S. (2014). An Assessment of Renolith on Cement-Stabilized Poor Lateritic Soils. Sci-Afric Journal of Scientific Issues, Research and Essays. 1st Academia Publishing London. Vol. 2 (5)

[9]. Petry, T.M and Little, D.N (2002). Review of Stabilization of Clays and Expansive Soils in Pavement and Lightly Loaded Structures-History, Practice and Future. Journal of Materials in Civil Engineering. Vol. 14 (6) .

[10]. Prakhar, D and Rajesh, J (2015). Effect of Common Salt $(\mathrm{NaCl})$ on Engineering Properties of Black Cotton Soil. International Journal of Science Technology and Engineering. Vol 2 (1)

[11]. Ramadas, T.L, Kumar, N.D and Yesuratnam, G (2012). A study on strength and swelling characteristics of three expansive soils treated with $\mathrm{CaCl}$. International Journal of Advances in Civil Engineering and Architecture. Vol 1 (1).

[12]. Sabat, A. K. (2012). A study on some geotechnical properties of lime stabilized expansive soil quarry dust mixes. International. Journal of .Emergency Trends in Engineering Development Vol.2 (1).

[13]. Singh, G. and Das, B. M. (1999). Soil Stabilization with Sodium Chloride. Transportation Research Record,

[14]. Subhashree, Samantasinghar. (2014). Geo-Engineering Properties of Lime treated Plastic soils. Dissertation, Department of Civil Engineering, National institute of technology Rourkela Rourkela-769008, Orissa, India May 2014.

[15]. Zumrawi, Magdi M.E and Hamza, Omer S.M (2014). Improving the Characteristics of Expansive Subgrade Soils Using Lime and Fly Ash. Vol 3 (12)

[16]. Zumrawi, Magdi M.E. (2015). Stabilization of Pavement Subgrade by Using Fly Ash Activated by Cement. American Journal of Civil Engineering and Architecture. Vol 3 (6), 